\title{
Industrial Emissions and Asthma Prevalence
}

\author{
Jennifer N. Sims ${ }^{1 *}$, Sophia S. Leggett ${ }^{1}$, Anitha Myla ${ }^{2}$
}

\author{
${ }^{1}$ Department of Behavioral and Environmental Health, School of Public Health, Jackson State University, MS, USA \\ ${ }^{2}$ Department of Environmental Science, Jackson State University, MS USA \\ *Corresponding Author: jennifer.n.sims@jsums.edu
}

Citation: Sims, J. N., Leggett, S. S. and Myla, A. (2020). Industrial Emissions and Asthma Prevalence. European Journal of Environment and Public Health, 4(2), em0046. https://doi.org/10.29333/ejeph/8288

\section{ARTICLE INFO}

Received: 31 Mar. 2020

Accepted: 14 May 2020

\begin{abstract}
The pathogenesis of asthma is multifactorial and not completely understood; however, it is considered a chronic inflammatory disease that affects the airways and has a clinical development of wheezing, shortness of breath, chest tightness, and cough. The prevalence of asthma has increased drastically during the past few decades. Urban air pollution from industrial emissions has been implicated as one of the major factors responsible for this increase. The objective of this paper was to analyze the impact of sulfur dioxide $\left(\mathrm{SO}_{2}\right)$, nitrogen oxides $\left(\mathrm{NO}_{\mathrm{x}}\right)$, and carbon dioxide $\left(\mathrm{CO}_{2}\right)$ on the overall prevalence of asthma for adults and children. The statistical analysis was conducted using SAS statistical software to determine multiple comparison tests for asthma prevalence among years, ages, ethnicities, and gender, and emissions of $\mathrm{SO}_{2}, \mathrm{NO}_{\mathrm{x}}$, and $\mathrm{CO}_{2}$ among regions and years. Moreover, SAS was utilized to estimate fully parametric regression models for emission density on total asthma prevalence, child asthma, and adult asthma. In our investigation of asthma prevalence, blacks, females, and children were found to have the highest incidence of asthma. Industrial emissions of $\mathrm{SO}_{2}, \mathrm{NO}_{\mathrm{x}}$, and $\mathrm{CO}_{2}$ were analyzed, and $\mathrm{CO}_{2}$ had the largest emissions, followed by $\mathrm{SO}_{2}$, and lastly $\mathrm{NO}_{\mathrm{x}}$. $\mathrm{NO}_{\mathrm{x}}$ had the highest correlation with asthma prevalence in child and adult asthma; however, when the influence of $\mathrm{SO}_{2}, \mathrm{NO}_{\mathrm{x}}$, and $\mathrm{CO}_{2}$ on the overall asthma rate was investigated, $\mathrm{CO}_{2}$ showed the highest correlation. Furthermore, children exposed to $\mathrm{SO}_{2}, \mathrm{NO}_{\mathrm{x}}$, and $\mathrm{CO}_{2}$ were found to have an increased risk of asthma when compared to adults. This adds to evidence that outdoor air pollution is associated with asthma and that more needs to be done to decrease industrial air pollution.
\end{abstract}

Keywords: asthma, industrial emissions, carbon dioxide, nitrogen oxides, sulfur dioxide

\section{INTRODUCTION}

Asthma is a substantial cause of morbidity and mortality whose prevalence has nearly increased 2 -folds in the past 20 years (Lim et al., 2007; Price et al., 2017). The pathogenesis of asthma is multifactorial and not completely understood; however, it is considered a chronic inflammatory disease that affects the airways and has a clinical development of wheezing, shortness of breath, chest tightness, and cough (Barrios et al., 2006, Edwards et al., 2017). Asthma is a growing concern and a major public health issue affecting $13 \%$ of the United States population (Nunes et al., 2017) and accounting for 3,396 deaths annually (Patel et al., 2018). There are approximately 26 million patients with physician-diagnosed asthma in the United States (US) (Yaghoubi et al., 2019). This chronic disease affects all ages and causes over 1 million emergency department visits and over 150,000 hospitalizations with a cost of approximately $\$ 80$ billion in medical expenses annually (Yaghoubi et al., 2019).

The propensity to acquire asthma can be inherited, but genetic components are unlikely to be the cause of this significant increase that has occurred in the past 20 years (Woodruff et al., 2004; Yang et al., 2017). Scientists have shown that air pollution from vehicles, industries, and power plants is a major source for asthma attacks (Anenberg et al., 2018). Scientific evidence has shown that several environmental pollutants, both indoor and outdoor, exacerbate asthma. These environmental pollutants include exposure to dust mites, tobacco smoke, cockroaches, nitrogen dioxide $\left(\mathrm{NO}_{2}\right)$, pesticides, plasticizers, and volatile organic compounds (VOCs) (Guarnieri and Balmes, 2014; Woodruff et al., 2004).

Current research is being conducted to fully understand the link between industrial emissions and asthma incidence and prevalence. There have been several studies showing that chronic exposure to ozone is associated with the development and exacerbation of asthma (Avol et al., 2001; Gauderman et al., 2002; Goodman et al., 2018; McConnell et al., 2002; Zu et al., 2017, 2018). Moreover, other studies found that exposure to particulate matter affects asthma (Cesar et al., 2016, Ware et al., 1993, Zuo et al., 2019). Lastly, industrial emissions of carbon dioxide $\left(\mathrm{CO}_{2}\right)$ and sulfur dioxide $\left(\mathrm{SO}_{2}\right)$ have been associated with asthma prevalence (Reno et al., 2015). 
Table 1. Description of Data Sources for Asthma and Air Pollutants

\begin{tabular}{|c|c|c|c|}
\hline Outcome & $\begin{array}{l}\text { Years } \\
\text { Available }\end{array}$ & Data Source & Data Description \\
\hline $\begin{array}{l}\text { Overall, Child, } \\
\text { and Adult } \\
\text { Asthma } \\
\text { Prevalence }\end{array}$ & 2006-2011 & $\begin{array}{l}\text { Centers for Disease Control and Prevention, } \\
\text { National Center for Health Statistics, } \\
\text { National Health Interview Survey } \\
\text { http://www.cdc.gov/asthma/nhis/default.htm }\end{array}$ & $\begin{array}{l}\text { The NHIS is a continuing nationwide sample survey of the civilian } \\
\text { non-institutionalized population collected by personal household } \\
\text { interviews. Data for regions (Northeast, Midwest, South, and West), } \\
\text { ages }(0-65+) \text { ethnicity (African American, Hispanic, and Caucasian), } \\
\text { and gender were given. The ages were given in } 8 \text { groups }(0-4,5-14 \text {, } \\
15-34,15-19,20-24,25-34,35-64 \text {, and } 65+) ; n=286\end{array}$ \\
\hline $\mathrm{SO}_{2}, \mathrm{NO}_{\mathrm{x}}, \mathrm{CO}_{2}$ & $2006-2010$ & $\begin{array}{l}\text { US Environmental Protection Agency } \\
\text { http://ampd.epa.gov/ampd/ }\end{array}$ & $\begin{array}{l}\text { Air Markets Program Data (AMPD) is a web-based application that } \\
\text { allows users easy access to both current and historical data collected } \\
\text { as part of EPA's emissions trading programs. Data for } \mathrm{SO}_{2}, \mathrm{NO}_{\mathrm{x}}, \mathrm{CO}_{2} \\
\text { by state were given in tons; } \mathrm{n}=245 \text { observations per pollutant. }\end{array}$ \\
\hline $\begin{array}{l}\text { Total Land } \\
\text { Area for each } \\
\text { State }\end{array}$ & $2006-2010$ & $\begin{array}{l}\text { http://www.census.gov/compendia/ } \\
\text { statab/2012/tables/12s0358.pdf }\end{array}$ & $\begin{array}{l}\text { US Census was used to get the total land area per state in acres to } \\
\text { calculate the concentration of pollutant per acre in each state } \\
\text { studied. }\end{array}$ \\
\hline
\end{tabular}

Nitrogen dioxide and nitric oxide are referred to together as nitrogen oxides $\left(\mathrm{NO}_{\mathrm{x}}\right)$. NOx gases react to form smog as well as being paramount to the development of fine particles (PM) and ground level ozone, both of which are linked with adverse health effects. A recent study revealed a statistically significant association between outpatient visits and hospitalizations due to bronchitis and asthma exacerbation and daily nitrogen oxides concentrations (Kowalska et al., 2020). With the continued industrialization worldwide, it is essential to refine our understanding of the mechanisms behind asthma associated with inhaled environmental exposure to air pollutants.

Power plants accounted for approximately $64 \%$ of $\mathrm{SO}_{2}$ emissions, $16 \%$ of $\mathrm{NO}_{\mathrm{x}}$ emissions, and $40 \%$ of $\mathrm{CO}_{2}$ emissions in the United States (Amster and Lew Levy, 2019; Massetti, 2017; Van Atten, 2012). Both $\mathrm{SO}_{2}$ and $\mathrm{NO}_{\mathrm{x}}$ are categorized as National Ambient Air Quality Standards (NAAQS) by the EPA due to their adverse effects on human health and the environment. $\mathrm{CO}_{2}$ is a notable greenhouse gas that thrives as a main pollutant that is warming the Earth. $\mathrm{CO}_{2}$ is considered to be a pollutant when associated with cars, planes, power plants, and other anthropogenic activities that involve the burning of fossil fuels such as gasoline and natural gas (Chen et al., 2020). Furthermore, $\mathrm{CO}_{2}$ is deemed as the most prevalent of anthropogenic greenhouse gas emission and the electric industry accounts for more $\mathrm{CO}_{2}$ emissions than any other sector, including industrial and transportation sectors (Quick and Marland, 2019).

Since the association of ground level ozone and particulate matter on asthma has been extensively studied, the focus of our study will examine the industrial emissions of the primary pollutants $\mathrm{SO}_{2}, \mathrm{NO}_{x}$, and $\mathrm{CO}_{2}$ on the prevalence of asthma. The objective of this paper was to determine the prevalence of asthma across the contiguous United States among regions, age, gender, and ethnicity (African American, Caucasian, or Hispanic) for 2006-2011. We also analyzed the emissions of $\mathrm{SO}_{2}, \mathrm{NO}_{\mathrm{x}}$, and $\mathrm{CO}_{2}$ by industries per region during 2006-2011. Lastly, we analyzed the impact of $\mathrm{SO}_{2}, \mathrm{NO}_{x}$, and $\mathrm{CO}_{2}$ on the overall prevalence of asthma, child asthma, and adult asthma. We hypothesize industrial emissions of $\mathrm{SO}_{2}, \mathrm{NO}_{\mathrm{x}}$, and $\mathrm{CO}_{2}$ are directly correlated with asthma prevalence for total asthma, child asthma, and adult asthma.

\section{METHODS}

\section{Data Collection}

The data used in this study is summarized in Table 1 . The Centers for Disease Control and Prevention, National Center for Health Statistics, National Health Interview Survey (NHIS) was used to determine the prevalence of asthma among region, age, race, and gender for 2006-2011. The NHIS is a continuing nationwide sample survey of the civilian non-institutionalized population gathered by personal household interviews. The United States Environmental Protection Agency (USEPA), Air Markets Program Data (AMPD), was employed to collect the industrial emissions of $\mathrm{SO}_{2}, \mathrm{NO}_{\mathrm{x}}$, and $\mathrm{CO}_{2}$ for each state during 2006-2011. The total land area for each state was retrieved from the United States Census Bureau to determine the density of emissions in tons per acre of land for each state.

\section{Data Analysis}

The data was stored and sorted in Microsoft Excel. The concentrations of the pollutants were given for each state; therefore, the data for each state had to be sorted and means calculated for each region (Table 2). The total land area for each state was retrieved and stored in Microsoft Excel (2010). The density of pollutant per state was found by taking the ratio of the total emissions per pollutant (tons) by the total land area for each state (acres). The density was then averaged per region. Once the data was sorted, the statistical analysis was conducted using SAS statistical software (Weaver and Wuensch, 2013). To find means and p-values, multiple comparison tests like PROC GLM/tukey (General Linear Models) was used to estimate asthma prevalence among years, ages, ethnicities, and gender, and emissions of $\mathrm{SO}_{2}, \mathrm{NO}_{\mathrm{x}}$, and $\mathrm{CO}_{2}$ among regions and years. Parametric regression model, PROC REG was used to estimate the relationships among emission density, total asthma prevalence, child asthma, and adult asthma. 
Table 2. Listing of states categorized into the four regions of the United States

\begin{tabular}{cccc}
\hline & Midwest & South & West \\
\hline Northeast States & Illinois & Alabama & Arizona \\
\hline Connecticut & Indiana & Arkansas & California \\
\hline Maine & Iowa & Delaware & Colorado \\
\hline Massachusetts & Kansas & District of Columbia (DC) & Idaho \\
\hline New Hampshire & Michigan & Florida & Montana \\
\hline New Jersey & Minnesota & Georgia & Nevada \\
\hline New York & Missouri & Kentucky & New Mexico \\
\hline Pennsylvania & Nebraska & Louisiana & Oregon \\
\hline Rhode Island & Morth Dakota & Uah & Washington \\
\hline Vermont & Ohio & Mississippi & Wyoming \\
\hline & South Dakota & North Carolina & \\
\hline & Wisconsin & Oklahoma & \\
\hline & South Carolina \\
\hline
\end{tabular}

West Virginia

The United States was divided into a total of four categories; Northeast, South, Midwest, and West. For our analysis, we did not include Hawaii or Alaska; however, the District of Columbia (DC) was listed as a State, tallying our State count to 49.

Table 3. Overall Asthma Prevalence from 2006-2011

\begin{tabular}{|c|c|c|c|}
\hline Year & Mean & Standard Deviation & P-value \\
\hline 2006 & 7.93 & 3.02 & 0.0786 \\
\hline 2007 & 8.60 & 3.46 & \\
\hline 2008 & 8.13 & 3.61 & \\
\hline 2009 & 8.30 & 4.03 & \\
\hline 2010 & 9.28 & 3.87 & \\
\hline 2011 & 9.09 & 3.67 & \\
\hline Gender & Mean & Standard Deviation & P-value \\
\hline Male & 7.95 & 4.17 & 0.0001 \\
\hline Female & 9.15 & 2.89 & \\
\hline Ethnicity & Mean & Standard Deviation & P-value \\
\hline African American & 10.90 & 4.26 & $<0.0001$ \\
\hline Hispanic & 6.62 & 2.55 & \\
\hline Caucasian & 8.10 & 2.35 & \\
\hline Age & Mean & Standard Deviation & P-value \\
\hline $0-4$ & 7.57 & 4.13 & $<0.0001$ \\
\hline $5-14$ & 12.26 & 4.64 & \\
\hline $15-34$ & 8.11 & 2.43 & \\
\hline $15-19$ & 10.11 & 3.14 & \\
\hline $20-24$ & 8.50 & 3.44 & \\
\hline $25-34$ & 6.98 & 2.44 & \\
\hline $35-64$ & 7.37 & 2.90 & \\
\hline $65+$ & 7.50 & 2.09 & \\
\hline
\end{tabular}

\section{RESULTS}

\section{Asthma Prevalence}

Table 3 and Figure 1 summarize the asthma prevalence. The p-values for the asthma prevalence among ages, ethnicity, and gender all had a p-value less than .05 while the asthma prevalence among years had a $\mathrm{p}$-value less than 0.10 . The statistical analysis revealed that the age groups (5-14) and (1519) have asthma prevalence means that were significantly different from all other age groups. Moreover ages 5-14 had a higher prevalence of asthma than any other age group. The other age groups did not have asthma prevalence means that were significantly different from any other age group. Blacks had the highest incidence of asthma when compared to Hispanics and Caucasians. All ethnicities have asthma prevalence means that were significantly different from each other (Table 4). Also, the means of asthma prevalence among gender were significantly different, and females had a greater incidence of asthma than males. The prevalence of asthma has been consistent from 2006-2011; thus, none of the years had significantly different means.

Our study determined the regional prevalence of total asthma, child asthma, and adult asthma during 2006-2011. The means of total asthma rates were placed in two groups: the Northeast and Midwest in one group while the South and West were in the other. This indicated that the means of total asthma prevalence were significantly different for the Northeast and Midwest when compared to the South and West. The means among child asthma was only significantly different in the West. Also, the West had the lowest incidence 

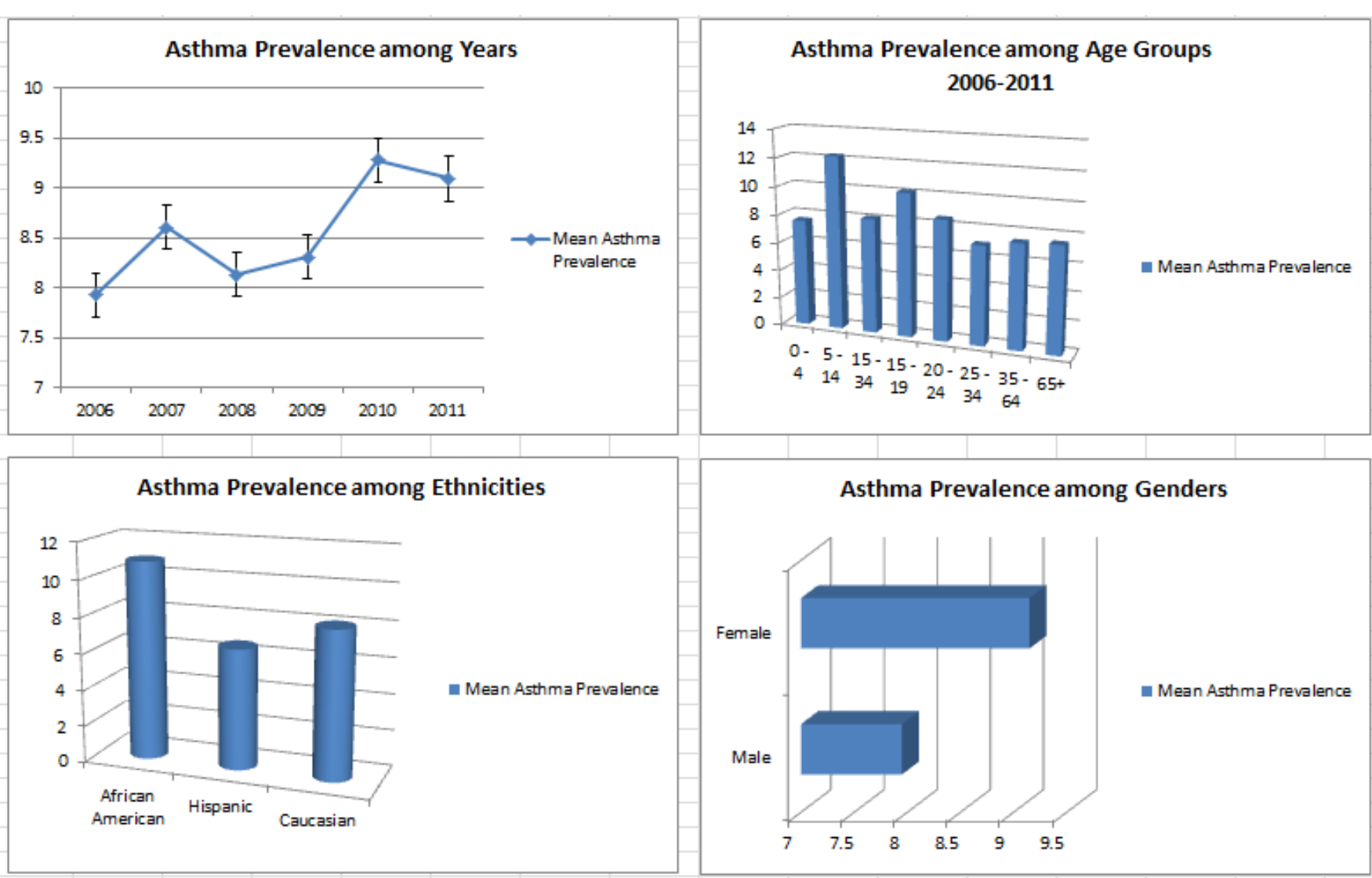

Figure 1. Asthma Prevalence among Year (A), Age (B), Ethnicity (C), and Gender (D)

Table 4. Ethnicity Comparison for Asthma Prevalence

\begin{tabular}{cccc}
\hline Ethnicity Comparison & Difference Between Means & Simultaneous & 95\% Confidence Limits \\
\hline African American - Caucasian & 2.8042 & 1.9108 & $3.6975^{* * * *}$ \\
\hline African American - Hispanic & 4.2818 & 3.3837 & $5.1799^{* * * * *}$ \\
\hline Caucasian - African American & -2.8042 & -3.6975 & $-1.9108^{* * * *}$ \\
\hline Caucasian - Hispanic & 1.4777 & 0.5796 & $2.3758^{* * * *}$ \\
\hline Hispanic - African American & -4.2818 & -5.1799 & $-3.3837^{* * * * *}$ \\
\hline Hispanic - Caucasian & -1.4777 & -2.3758 & $-0.5796^{* * * *}$ \\
\hline
\end{tabular}

of child asthma when compared to other regions. In adult asthma, the Northeast and South had significantly different means. Figure 2 shows the incidence of child asthma and adult asthma by region. Figure 3 illustrates the distribution of the data for total asthma, child asthma, and adult asthma.

\section{Regional Emissions of $\mathrm{SO}_{2}, \mathrm{NO}_{x}$, and $\mathrm{CO}_{2}$ during 2006-} 2011

The regional emissions of $\mathrm{SO}_{2}, \mathrm{NO}_{\mathrm{x}}$, and $\mathrm{CO}_{2}$ were determined by grouping the states into regions and finding the mean of each region. $\mathrm{CO}_{2}$ levels were much higher than $\mathrm{SO}_{2}$ and $\mathrm{NO}_{\mathrm{x}}$ levels; therefore, $\mathrm{CO}_{2}$ was illustrated separately from $\mathrm{SO}_{2}$ and $\mathrm{NO}_{\mathrm{x}}$. As shown in Figure 4, the emissions of $\mathrm{SO}_{2}$ were greater than the emissions of $\mathrm{NO}_{\mathrm{x}}$. Also, from 2006 through 2011, the levels of emissions for both $\mathrm{SO}_{2}$ and $\mathrm{NO}_{\mathrm{x}}$ have declined. The Midwest and South had the highest emissions of $\mathrm{SO}_{2}$ and $\mathrm{NO}_{\mathrm{x}}$ during 2006 to 2011 than any other region (Figure 4). $\mathrm{CO}_{2}$ levels were highest in the Midwest and South during 2006 - 2009, and 2011. However, the West experienced an extreme increase in $\mathrm{CO}_{2}$ levels in 2010 (Figure 5). The statistical analysis revealed that the Northeast and West had significantly different means than the Midwest and South for
$\mathrm{SO}_{2}$ and $\mathrm{NO}_{\mathrm{x}}$ while there were no regions with significantly different means for $\mathrm{CO}_{2}$ (Figure 6).

The Impact of $\mathrm{SO}_{2}, \mathrm{NO}_{\mathrm{x}}$, and $\mathrm{CO}_{2}$ Asthma Prevalence

The impact of $\mathrm{SO}_{2}, \mathrm{NO}_{\mathrm{x}}$, and $\mathrm{CO}_{2}$ on total asthma prevalence was investigated in this study. The results yielded a weak correlation between $\mathrm{SO}_{2}, \mathrm{NO}_{\mathrm{x}}$, and $\mathrm{CO}_{2}$ on the total prevalence of asthma (Figure 7); however, $\mathrm{CO}_{2}$ had the strongest correlation $\left(\mathrm{R}^{2}=.3027\right)$ when compared to $\mathrm{SO}_{2}$ and $\mathrm{NO}_{\mathrm{x}}$ on the total asthma prevalence. We also evaluated the correlation between $\mathrm{SO}_{2}, \mathrm{NO}_{\mathrm{x}}$, and $\mathrm{CO}_{2}$ on child and adult asthma separately. These results differ greatly from the overall asthma correlations. There was a stronger correlation $\left(\mathrm{R}^{2}=0.5998\right)$ found between $\mathrm{NO}_{\mathrm{x}}$ and child asthma (Figure 8) when compared to any other correlation in the study. Furthermore, $\mathrm{SO}_{2}\left(\mathrm{R}^{2}=.4501\right)$ contributes to child asthma more than $\mathrm{CO}_{2}\left(\mathrm{R}^{2}=.3927\right)$. Correlations among adult asthma and $\mathrm{SO}_{2}, \mathrm{NO}_{\mathrm{x}}$, and $\mathrm{CO}_{2}$ were determined (Figure 9). $\mathrm{NO}_{\mathrm{x}}$ had the highest correlation $\left(\mathrm{R}^{2}=.2253\right)$ among adult asthma followed by $\mathrm{SO}_{2}\left(\mathrm{R}^{2}=.1813\right)$ and finally $\mathrm{CO}_{2}\left(\mathrm{R}^{2}=.0196\right)$. 
Child Asthma vs. Adult Asthma

2006-2011

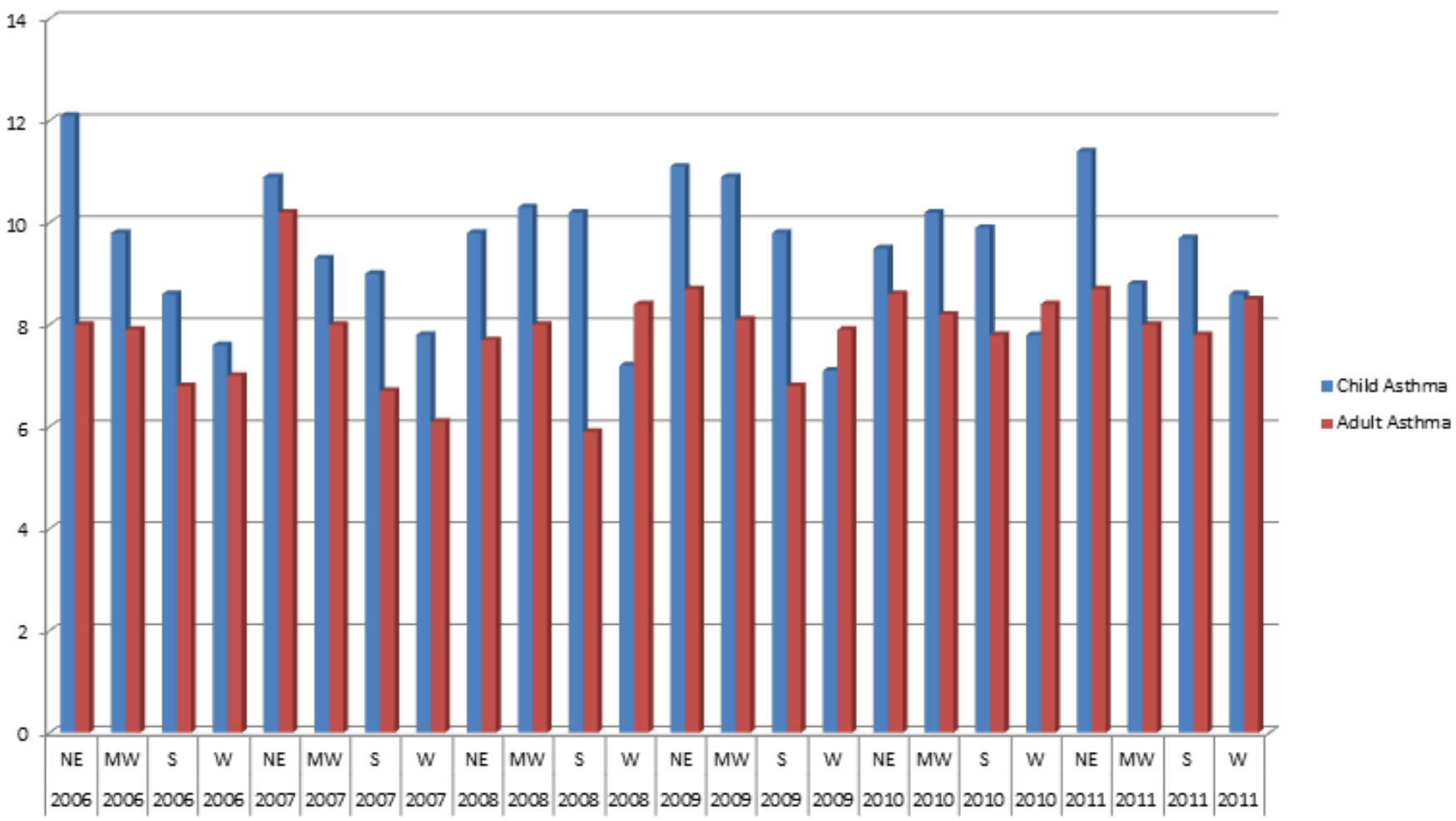

Figure 2. Regional Child and Adult Asthma Prevalence during 2006-2011

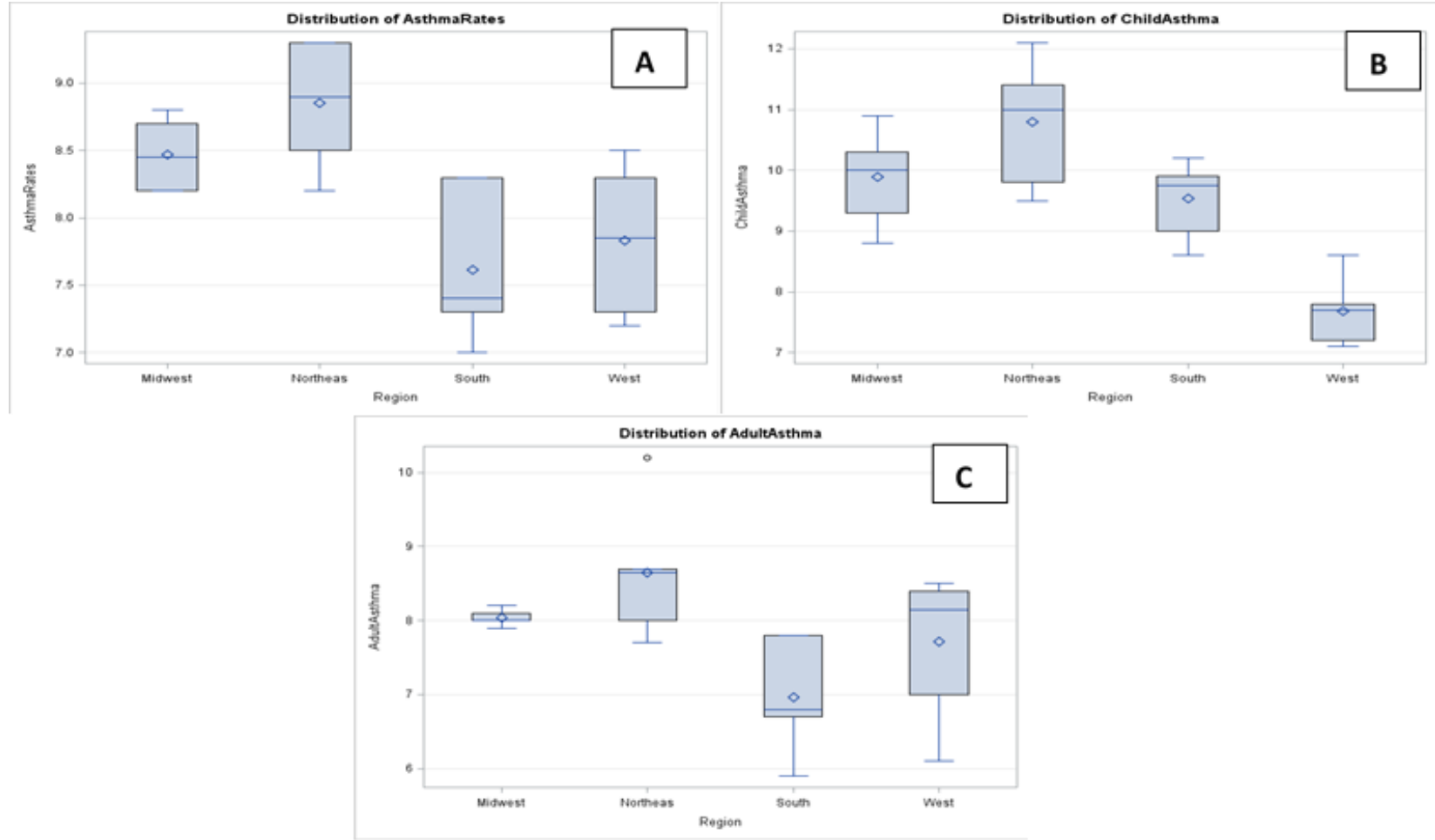

Figure 3. Distribution of Regional Overall Asthma Rates (A), Child Asthma (B), and Adult Asthma (C). This illustration depicts the distribution of the data for total asthma prevalence, child asthma, and adult asthma 


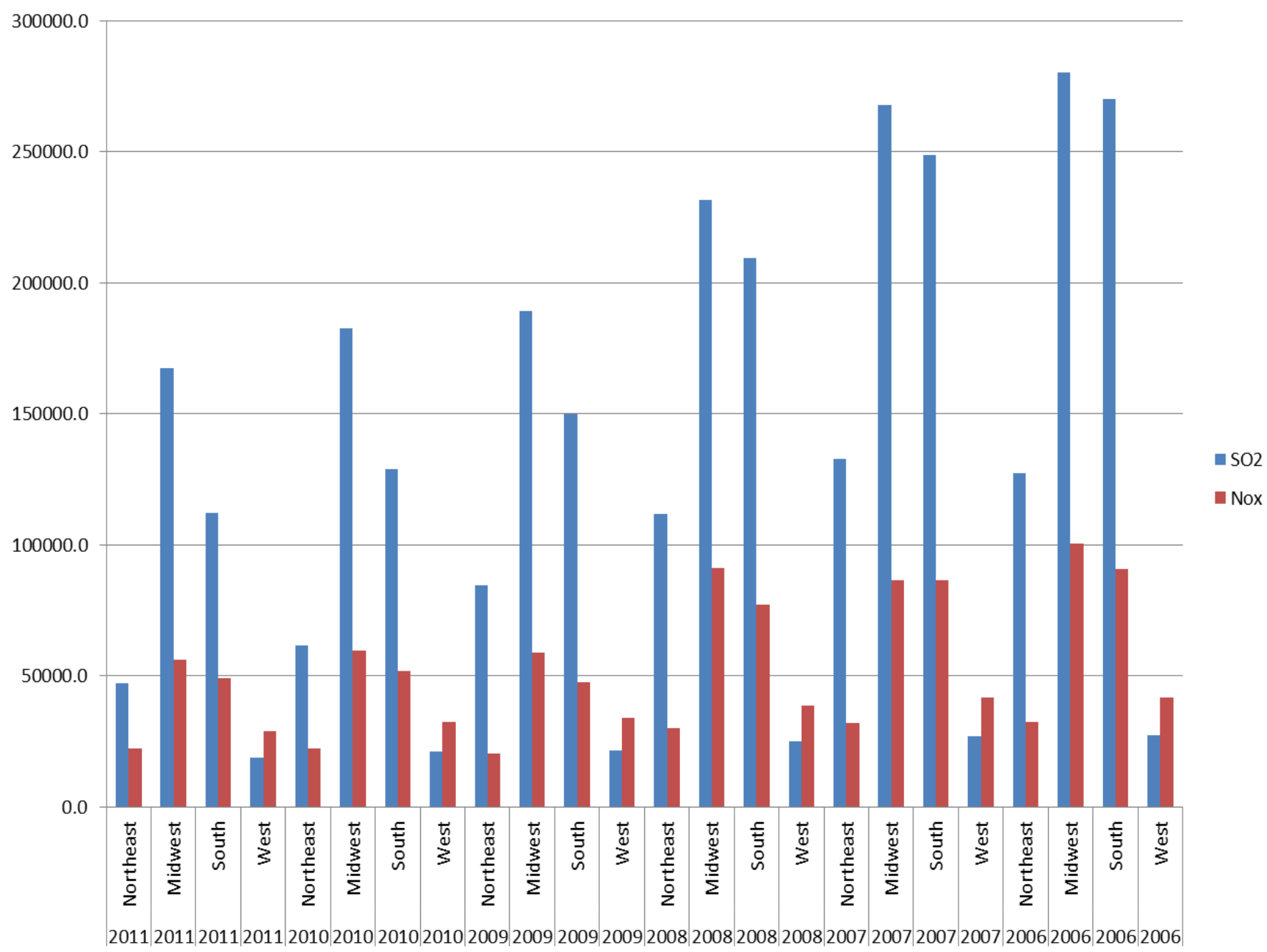

Figure 4. Regional $\mathrm{SO}_{2}$ and $\mathrm{NO}_{x}$ Emissions during 2006-2011

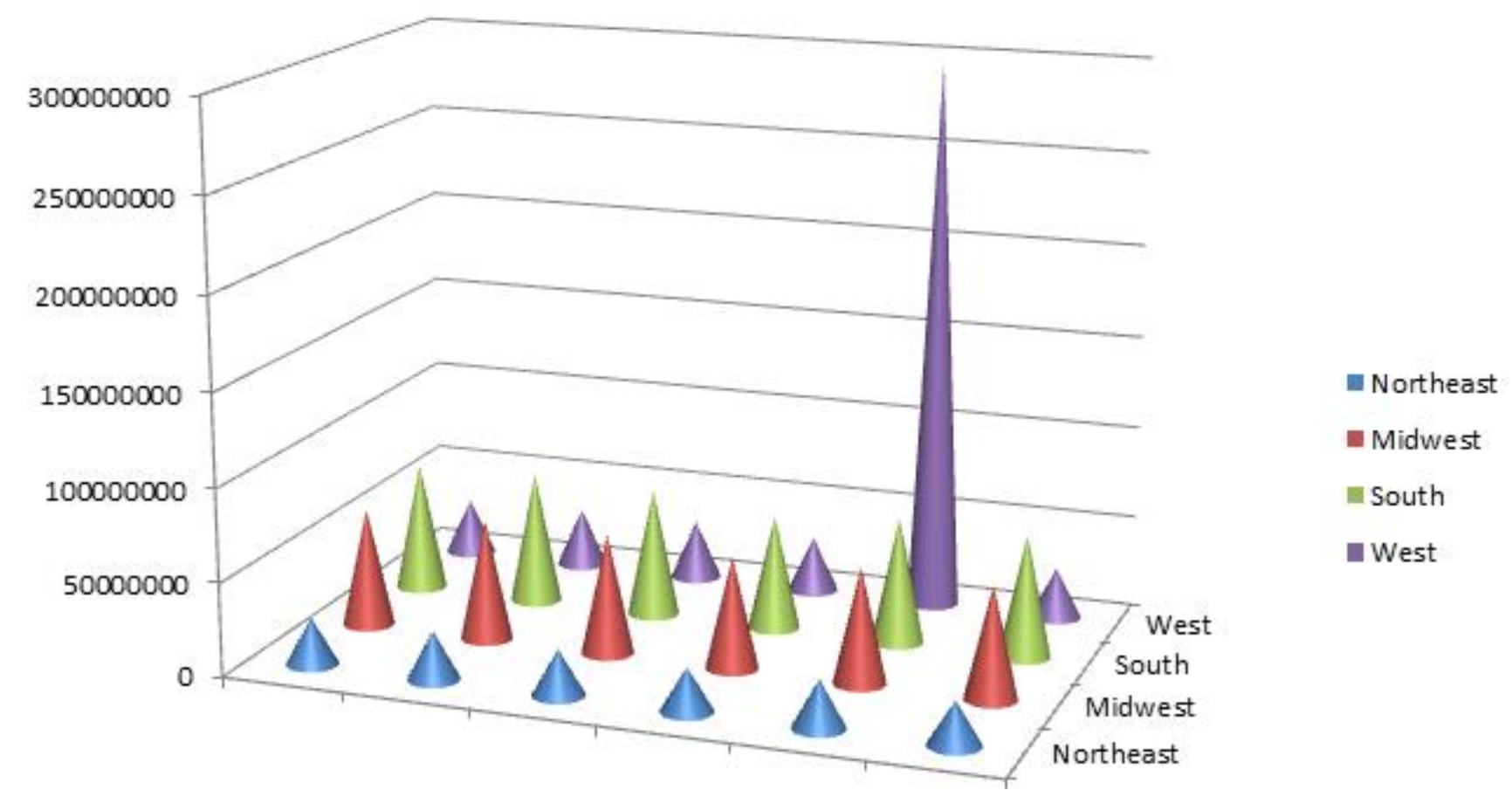

Figure 5. Regional $\mathrm{CO}_{2}$ Emissions during 2006-2011 


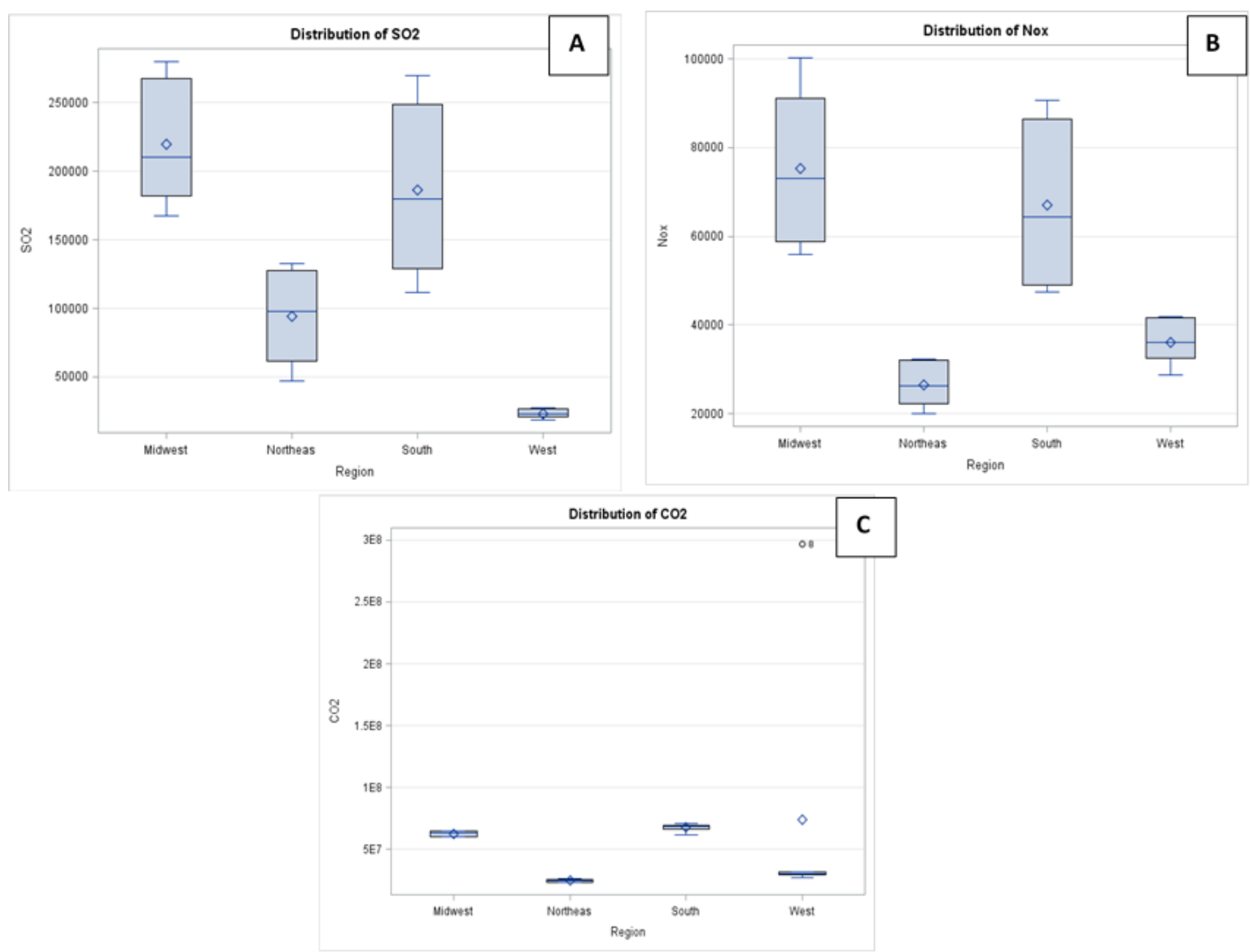

Figure 6. Distribution of Regional $\mathrm{SO}_{2}, \mathrm{NO}_{x}$, and $\mathrm{CO}_{2}$. This figure illustrates the distribution of regional emissions of $\mathrm{SO}_{2}, \mathrm{NO}_{\mathrm{x}}$, and $\mathrm{CO}_{2}$

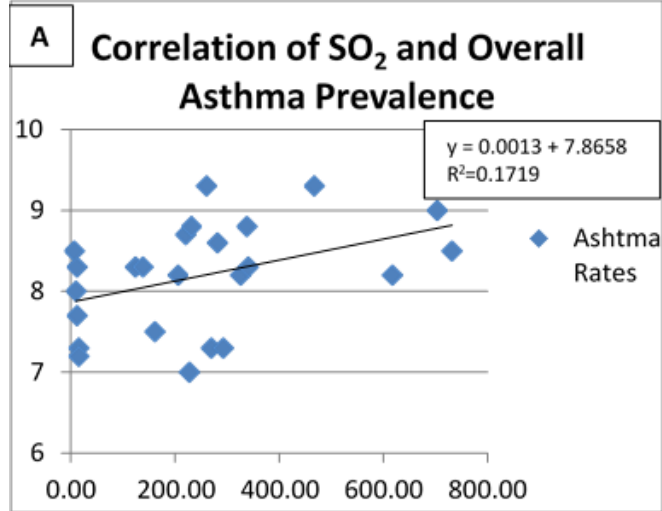
B Correlation of $\mathrm{NO}_{x}$ and Overall
Asthma Prevalence

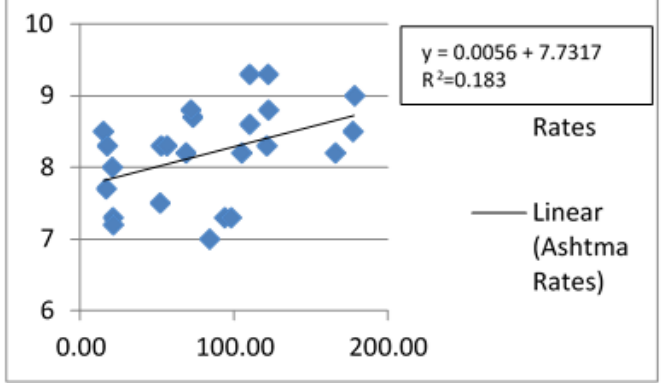

\section{Correlation of $\mathrm{CO}_{2}$ and Overall \\ Asthma Prevalence}

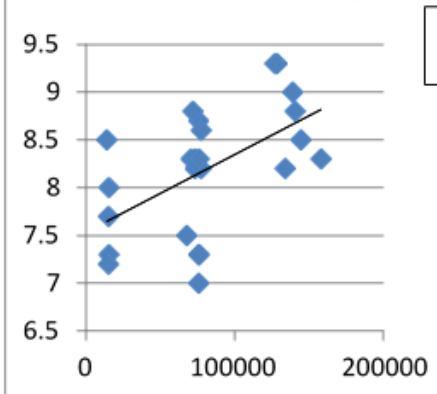

$y=8 E-06 x+7.5364$ $R^{2}=0.3027$

- Asthma

Rates

Linear

(Asthma

Rates)

Figure 7. Regression of $\mathrm{SO}_{2}(\mathrm{~A}), \mathrm{NO}_{\mathrm{x}}(\mathrm{B})$, and $\mathrm{CO}_{2}(\mathrm{~B})$ on Total Asthma Prevalence 

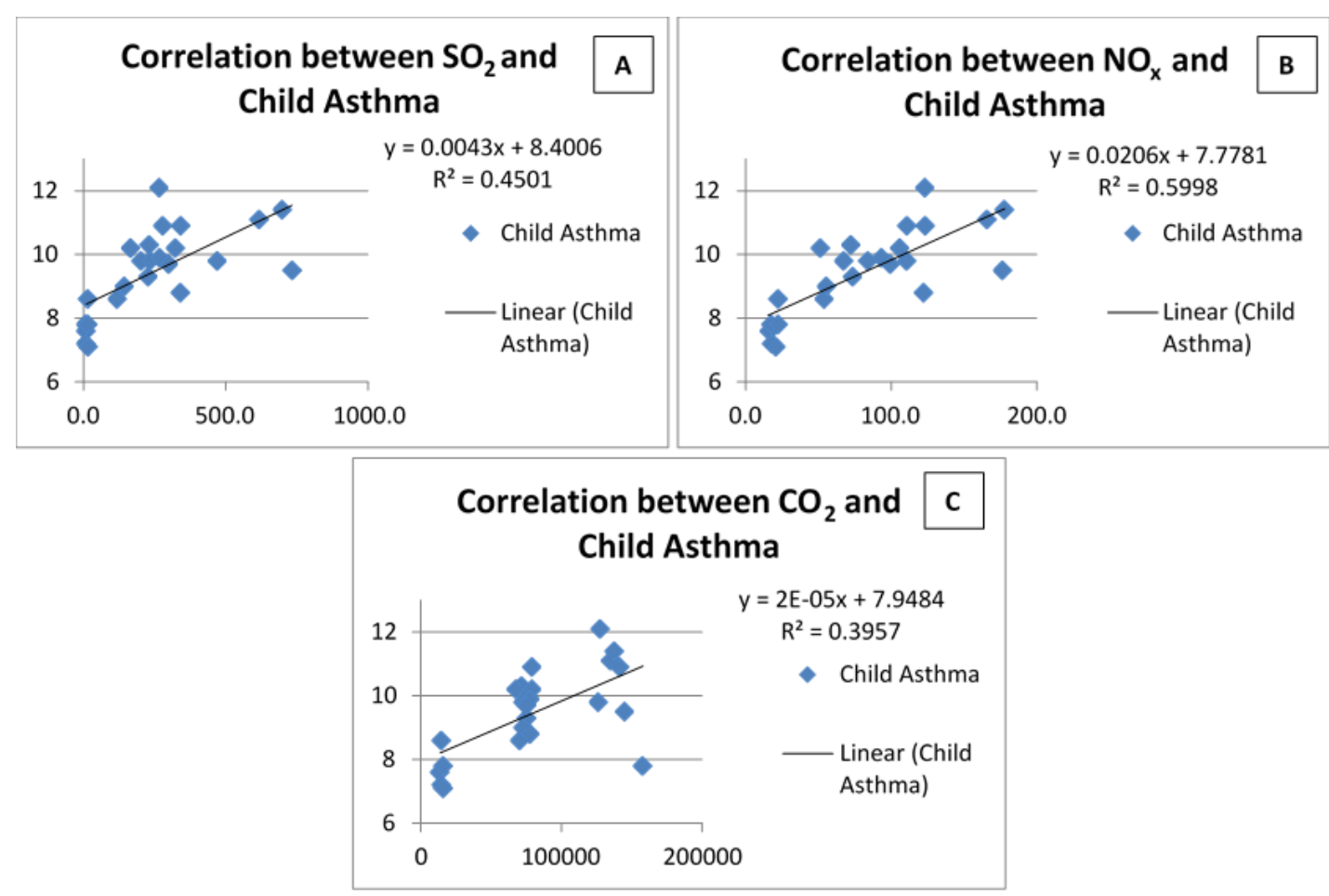

Figure 8. Regression of $\mathrm{SO}_{2}(\mathrm{~A}), \mathrm{NO}_{\mathrm{x}}(\mathrm{B})$, and $\mathrm{CO}_{2}(\mathrm{~B})$ on Prevalence of Child Asthma
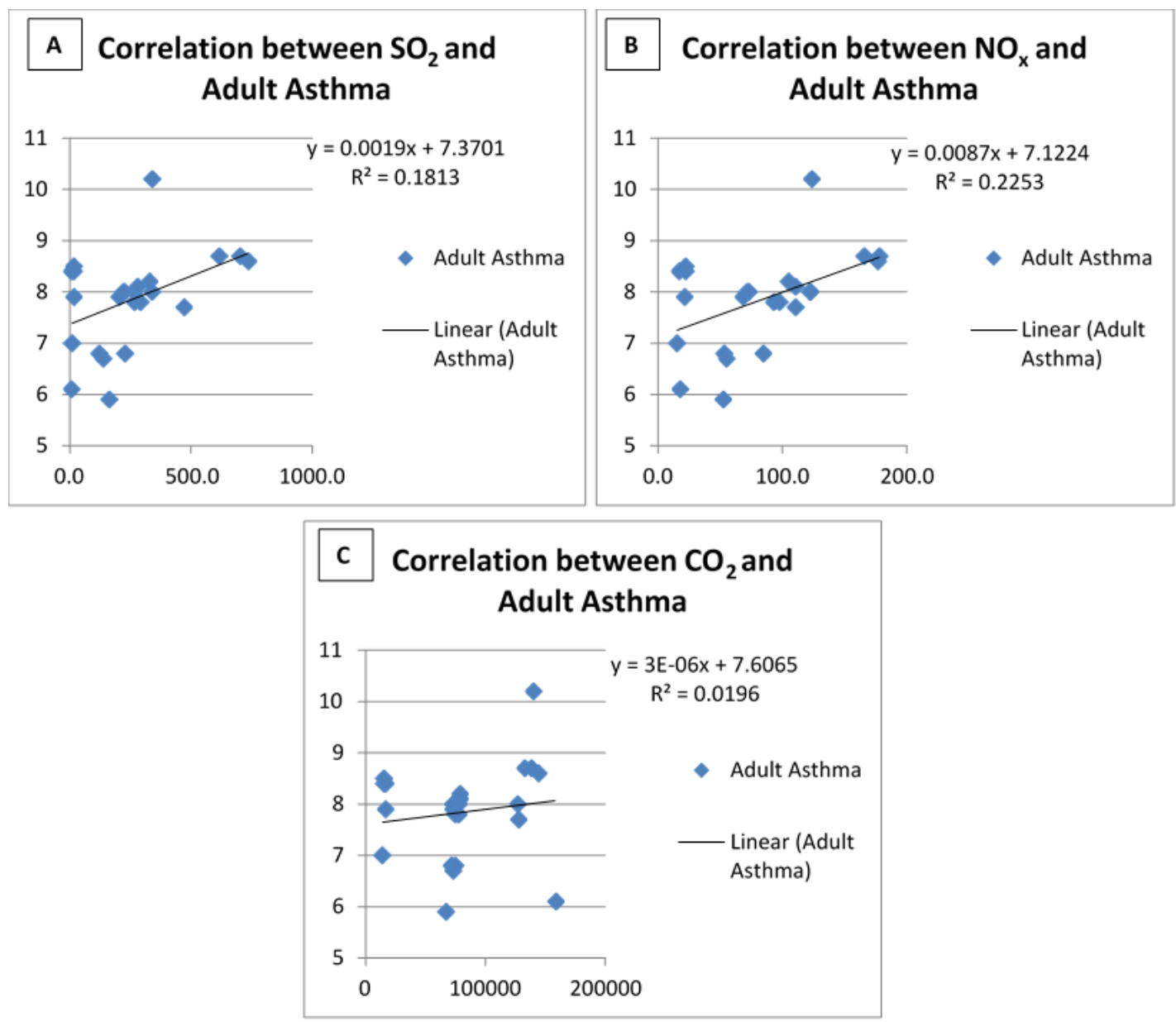

Figure 9. Regression of $\mathrm{SO}_{2}(\mathrm{~A}), \mathrm{NO}_{\mathrm{x}}(\mathrm{B})$, and $\mathrm{CO}_{2}(\mathrm{~B})$ on Prevalence of Adult Asthma 


\section{DISCUSSION}

Our study found the prevalence of asthma among years, regions, ages, ethnicities, and gender during 2006-2011. African ancestry has been linked to asthma, and elevated asthma rates in blacks can be partially attributed to African genetic ancestry (Daya and Barnes, 2019; Flores et al., 2012). Moreover, asthma prevalence is disproportionately high among African American women in the United States (Janevic et al., 2012; Tran and Tran, 2020). Epidemiological studies have shown that the prevalence of adult asthma and severe asthma is higher in women (Fuseini and Newcomb, 2017; Takeda et al., 2013). Our study confirms previous research regarding blacks and women having the highest prevalence for asthma in the United States. The causation of this high prevalence among has not been fully found; however, lower socioeconomical status and less education has been associated with being the main culprits for blacks carrying such a high prevalence for asthma.

Asthma is much more common in children than adults. Asthma is the most common chronic childhood disease that affects nearly 7 million children in the United States (Orellano et al., 2017). Non-Hispanic black children have been reported to be more likely to have ever been diagnosed with asthma (22\%) or to still have asthma (17\%) than Hispanic children $13 \%$ (ever diagnosed) and 8\% (still diagnosed) or non-Hispanic white children (12\% and $8 \%$, respectively) (Walker, 2012). Our study had similar results that children aged 5 to 14 and 15 to 19 had the highest prevalence for asthma when compared to any other age group.

Our study validated that power plant emissions of $\mathrm{SO}_{2}$ were greater than the emissions of $\mathrm{NO}_{\mathrm{x}}$ (Massetti, 2017). Our collected data also determined that from 2006 through 2011, the levels of emissions for both pollutants have declined. We also found that emissions of $\mathrm{CO}_{2}$ drastically surpassed that of $\mathrm{SO}_{2}$ and $\mathrm{NO}_{\mathrm{x}}$ during 2006 to 2011. M. J. Bradley \& Associates (2012) stated that the total generation among the 100 largest power producers for 2010 had $\mathrm{SO}_{2}$ emissions ranging from 0 to 498,009 tons, $\mathrm{NO}_{\mathrm{x}}$ emissions ranging from 0 to 129,951 tons, $\mathrm{CO}_{2}$ emissions ranging from 0 to 155 million tons. $\mathrm{CO}_{2}$ emissions from power plants are largely unregulated at the federal level (Van Atten, 2012). Thus, more $\mathrm{CO}_{2}$ is being released. Since 1990, there has been a notable decrease in the power plant emissions of $\mathrm{SO}_{2}$ and $\mathrm{NO}_{\mathrm{x}}$ (Massetti, 2017). This was seen in our study as well. M. J. Bradley \& Associates (2012) reported that there has been a $68 \%$ decline of $\mathrm{NO}_{\mathrm{x}}$ and $\mathrm{SO}_{2}$ emissions from 1991 to 2010 due to the implementation of the 1990 Clean Air Act Amendments (Van Atten, 2012). However, the Clean Air Act amendments did not contain any regulations for $\mathrm{CO}_{2}$; therefore, the emissions of $\mathrm{CO}_{2}$ have increased since 1990. In 2010, power plant emissions of $\mathrm{CO}_{2}$ were $24 \%$ higher than 1990, and between 2009 and 2010, power plant emissions of $\mathrm{CO}_{2}$ increased by $5 \%$ due to economic growth resulting in higher energy consumption across all sectors (Van Atten, 2012). The electric power industry is constantly transforming as new policies and procedures are in place in order to reduce air pollution emissions. Furthermore, the industrial companies are deciding to discontinue the use in the number of coal-fired generating plants as natural gas prices has declined making the use of fossil-fired power plants more economically feasible (Massetti, 2017).

Our study also investigated the impact of $\mathrm{SO}_{2}, \mathrm{NO}_{\mathrm{x}}$, and $\mathrm{CO}_{2}$ on overall asthma prevalence, child asthma, and adult asthma. The highest correlation between the three pollutants of interest was found in child asthma compared to overall asthma prevalence and adult asthma. Therefore, children exposed to $\mathrm{SO}_{2}, \mathrm{NO}_{\mathrm{x}}$, and $\mathrm{CO}_{2}$ have elevated risks of asthma. Children are more susceptible to asthma and other respiratory illnesses (Goldizen et al., 2016; Perera, 2017; Tzivian, 2011). The National Academy of Sciences has found that in general, children are more susceptible to environmental toxins than adults because children consume more food and water relative to their total body surface area compared to adults. Therefore, they are exposed to more environmental toxins relative to their body mass index. Children also have a more rapid respiratory rate and take in a greater volume of air per unit of body mass index than adults (Orellano et al., 2017; Tzivian, 2011). Moreover, children's organs systems are immature making them more vulnerable and less able to detoxify hazardous chemicals. Also, human lungs do not develop completely until the sixth to eighth year of life. During these early years, exposure to even mild chemical irritants can have significant effects on respiratory development (Goldizen et al., 2016; Tzivian, 2011).

The prevalence of asthma has increased drastically during the past few decades. Urban air pollution from industrial emissions has been implicated as one of the major factors responsible for this increase. Our study revealed industrial emissions of $\mathrm{CO}_{2}$ as being associated with total asthma prevalence. Anthropogenic increases in global atmospheric $\mathrm{CO}_{2}$ concentration have been shown to stimulate earlier and greater production of allergenic pollen (Reinmuth-Selzle et al., 2017, Wolf et al., 2010). Studies have shown that a doubling of the atmospheric $\mathrm{CO}_{2}$ concentration stimulated ragweedpollen production by $61 \%(\mathrm{P}=0.005)$ (D'Amato et al., 2013, D'Amato et al., 2016). $\mathrm{CO}_{2}$ may also increase airborne fungal spores (Pringle, 2013, Wolf et al., 2010). Pollen and fungal spores are known aggravators of asthma. Thus, increase concentration of $\mathrm{CO}_{2}$ may exacerbate asthma by increasing the production of pollen and fungal spores.

Children asthma was found to be affected most by $\mathrm{NO}_{\mathrm{x}}$ than the other pollutants that were studied. $\mathrm{NO}_{2}$ levels in the ambient air have been shown to be associated with emergency department visits for pediatric asthma (Burbank and Peden, 2018; Strickland et al., 2010). Studies found a statistically significantly increased risk of asthma diagnosis with increased early life exposure to $\mathrm{NO}$ and $\mathrm{NO}_{2}$ (Clark et al., 2010; Khreis et al., 2017). This data supports that early childhood exposure to air pollutants plays a role in development of asthma. Lobdell et al (2011) used traditional epidemiological study designs in small communities in New Haven to identify linkages between reduction in $\mathrm{NO}_{\mathrm{x}}$ and improvements in prevalence of asthma in children and adults (Lobdell et al., 2011). They concluded that a substantial reduction in air pollution (e.g., 60\% for $\mathrm{NO}_{\mathrm{x}}$ ) are needed to improve health impacts of pollutants on asthma (Lobdell et al., 2011). $\mathrm{NO}_{\mathrm{x}}$ is a principal precursor for the formation of ground level $\mathrm{O}_{3} . \mathrm{NO}_{x}$ has a direct correlation with $\mathrm{O}_{3}$ in the atmosphere and in the ambient air. Several studies report that chronic exposure to ozone is associated 
with the development of asthma (Avol et al., 2001; Gauderman et al., 2002; Goodman et al., 2018; McConnell et al., 2002; Schultz et al., 2017). Therefore, $\mathrm{NO}_{\mathrm{x}}$ is not only exacerbating asthma by itself, but it is also affecting asthma by producing $\mathrm{O}_{3}$.

\section{CONCLUSION}

In our investigation of asthma prevalence, blacks, females, and children were found to have the highest incidence of asthma. Industrial emissions of $\mathrm{SO}_{2}, \mathrm{NO}_{\mathrm{x}}$, and $\mathrm{CO}_{2}$ were analyzed, and $\mathrm{CO}_{2}$ had the largest emissions, followed by $\mathrm{SO}_{2}$, and lastly $\mathrm{NO}_{\mathrm{x}}$. However, $\mathrm{NO}_{\mathrm{x}}$ had the highest correlation with asthma prevalence in child and adult asthma. But, when the influence of $\mathrm{SO}_{2}, \mathrm{NO}_{\mathrm{x}}$, and $\mathrm{CO}_{2}$ on the overall asthma rate was investigated, $\mathrm{CO}_{2}$ showed the highest correlation. Furthermore, children exposed to $\mathrm{SO}_{2}, \mathrm{NO}_{\mathrm{x}}$, and $\mathrm{CO}_{2}$ were found to have an increased risk of asthma when compared to adults. This adds to evidence that outdoor air pollution is associated with asthma. The risk increase is small; however, the risk independently or jointly with genetic factors may explain why the prevalence of asthma has risen in the past 20 years.

\section{ACKNOWLEDGEMENTS}

This research was supported by the Department of Education, Historically Black Graduates Institutes (HBGI) Grant No. P031K190018.

\section{REFERENCES}

Amster, E. and Lew Levy, C. (2019). Impact of Coal-fired Power Plant Emissions on Children's Health: A Systematic Review of the Epidemiological Literature. Int J Environ Res Public Health, 16. https://doi.org/10.3390/ijerph16112008

Anenberg, S. C., Henze, D. K., Tinney, V., Kinney, P. L., Raich, W., Fann, N., ... Kuylenstierna, J. C. I. (2018). Estimates of the Global Burden of Ambient [Formula: see text], Ozone, and [Formula: see text] on Asthma Incidence and Emergency Room Visits. Environ Health Perspect, 126, 107004. https://doi.org/10.1289/EHP3766

Avol, E. L., Gauderman, W. J., Tan, S. M., London, S. J. and Peters, J. M. (2001). Respiratory effects of relocating to areas of differing air pollution levels. Am J Respir Crit Care Med, 164, 2067-2072. https://doi.org/10.1164/ajrccm. 164.11.2102005

Barrios, R. J., Kheradmand, F., Batts, L. and Corry, D. B. (2006). Asthma: pathology and pathophysiology. Arch Pathol Lab Med, 130, 447-451. https://doi.org/10.1043/1543-2165 (2006)130[447:Apap]2.0.Co;2

Burbank, A. J. and Peden, D. B. (2018). Assessing the impact of air pollution on childhood asthma morbidity: how, when, and what to do. Curr Opin Allergy Clin Immunol, 18, 124131. https://doi.org/10.1097/ACI.0000000000000422
Cesar, A. C., Nascimento, L. F., Mantovani, K. C. and Pompeo Vieira, L. C. (2016). [Fine particulate matter estimated by mathematical model and hospitalizations for pneumonia and asthma in children]. Rev Paul Pediatr, 34, 18-23. https://doi.org/10.1016/j.rppede.2015.12.005

Chen, R. Y., Ho, K. F., Chang, T. Y., Hong, G. B., Liu, C. W. and Chuang, K. J. (2020). In-vehicle carbon dioxide and adverse effects: An air filtration-based intervention study. Sci Total Environ, 723, 138047. https://doi.org/10.1016/j.scitotenv. 2020.138047

Clark, N. A., Demers, P. A., Karr, C. J., Koehoorn, M., Lencar, C., Tamburic, L. and Brauer, M. (2010). Effect of early life exposure to air pollution on development of childhood asthma. Environ Health Perspect, 118, 284-290. https://doi.org/10.1289/ehp.0900916

D’amato, G., Baena-Cagnani, C. E., Cecchi, L., AnnesiMaesano, I., Nunes, C., Ansotegui, I., ... Canonica, W. G. (2013). Climate change, air pollution and extreme events leading to increasing prevalence of allergic respiratory diseases. Multidiscip Respir Med, 8, 12. https://doi.org/10.1186/2049-6958-8-12

D’amato, G., Pawankar, R., Vitale, C., Lanza, M., Molino, A., Stanziola, A., ... D'amato, M. (2016). Climate Change and Air Pollution: Effects on Respiratory Allergy. Allergy Asthma Immunol Res, 8, 391-395. https://doi.org/10.4168/ aair.2016.8.5.391

Daya, M. and Barnes, K. C. (2019). African American ancestry contribution to asthma and atopic dermatitis. Ann Allergy Asthma Immunol, 122, 456-462. https://doi.org/10.1016/ j.anai.2019.02.009

Edwards, M. R., Saglani, S., Schwarze, J., Skevaki, C., Smith, J. A., Ainsworth, B., ... Members Of The, E. W. P. W. G. (2017). Addressing unmet needs in understanding asthma mechanisms: From the European Asthma Research and Innovation Partnership (EARIP) Work Package (WP)2 collaborators. Eur Respir J, 49. https://doi.org/10.1183/ 13993003.02448-2016

Flores, C., Ma, S. F., Pino-Yanes, M., Wade, M. S., PerezMendez, L., Kittles, R. A., ... Garcia, J. G. (2012). African ancestry is associated with asthma risk in African Americans. PLoS One, 7, e26807. https://doi.org/10.1371/ journal.pone.0026807

Fuseini, H. and Newcomb, D. C. (2017). Mechanisms Driving Gender Differences in Asthma. Curr Allergy Asthma Rep, 17, 19. https://doi.org/10.1007/s11882-017-0686-1

Gauderman, W. J., Gilliland, G. F., Vora, H., Avol, E., Stram, D., Mcconnell, R., ... Peters, J. M. (2002). Association between air pollution and lung function growth in southern California children: results from a second cohort. $A m \mathrm{~J}$ Respir Crit Care Med, 166, 76-84. https://doi.org/10.1164/rccm.2111021

Goldizen, F. C., Sly, P. D. and Knibbs, L. D. (2016). Respiratory effects of air pollution on children. Pediatr Pulmonol, 51, 94-108. https://doi.org/10.1002/ppul.23262 
Goodman, J. E., Zu, K., Loftus, C. T., Lynch, H. N., Prueitt, R. L., Mohar, I., Shubin, S. P. and Sax, S. N. (2018). Short-term ozone exposure and asthma severity: Weight-of-evidence analysis. Environ Res, 160, 391-397. https://doi.org/10.1016/j.envres.2017.10.018

Guarnieri, M. and Balmes, J. R. (2014). Outdoor air pollution and asthma. Lancet, 383, 1581-1592. https://doi.org/10.1016/S0140-6736(14)60617-6

Janevic, M. R., Sanders, G. M., Thomas, L. J., Williams, D. M., Nelson, B., Gilchrist, E., Johnson, T. R. and Clark, N. M. (2012). Study protocol for Women of Color and Asthma Control: a randomized controlled trial of an asthmamanagement intervention for African American women. BMC Public Health, 12, 76. https://doi.org/10.1186/14712458-12-76

Khreis, H., Kelly, C., Tate, J., Parslow, R., Lucas, K. and Nieuwenhuijsen, M. (2017). Exposure to traffic-related air pollution and risk of development of childhood asthma: A systematic review and meta-analysis. Environ Int, 100, 131. https://doi.org/10.1016/j.envint.2016.11.012

Kowalska, M., Skrzypek, M., Kowalski, M. and Cyrys, J. (2020). Effect of NOx and NO2 Concentration Increase in Ambient Air to Daily Bronchitis and Asthma Exacerbation, Silesian Voivodeship in Poland. Int J Environ Res Public Health, 17. https://doi.org/10.3390/ijerph17030754

Lim, R. H., Arredouani, M. S., Fedulov, A., Kobzik, L. and Hubeau, C. (2007). Maternal allergic contact dermatitis causes increased asthma risk in offspring. Respir Res, 8, 56. https://doi.org/10.1186/1465-9921-8-56

Lobdell, D. T., Isakov, V., Baxter, L., Touma, J. S., Smuts, M. B. and Ozkaynak, H. (2011). Feasibility of assessing public health impacts of air pollution reduction programs on a local scale: New Haven case study. Environ Health Perspect, 119, 487-493. https://doi.org/10.1289/ehp.1002636

Massetti, E., Brown, Marilyn A., Lapsa, M., Sharma, I., Bradbury, J., Cunliff, C. and Li, Y. (2017). Environmental Quality and the U.S. Power Sector: Air Quality, Water Quality, Land Use and Environmental Justice. In: Oak Ridge National Park, U. D. O. E. (ed.). United States. https://doi.org/10.2172/1339359

McConnell, R., Berhane, K., Gilliland, F., London, S. J., Islam, T., Gauderman, W. J., ... Peters, J. M. (2002). Asthma in exercising children exposed to ozone: a cohort study. Lancet, 359, 386-391. https://doi.org/10.1016/S01406736(02)07597-9

Nunes, C., Pereira, A. M. and Morais-Almeida, M. (2017). Asthma costs and social impact. Asthma Res Pract, 3, 1. https://doi.org/10.1186/s40733-016-0029-3

Orellano, P., Quaranta, N., Reynoso, J., Balbi, B. and Vasquez, J. (2017). Effect of outdoor air pollution on asthma exacerbations in children and adults: Systematic review and multilevel meta-analysis. PLoS One, 12, e0174050. https://doi.org/10.1371/journal.pone.0174050

Patel, O., Syamlal, G., Wood, J., Dodd, K. E. and Mazurek, J. M. (2018). Asthma Mortality Among Persons Aged 15-64 Years, by Industry and Occupation - United States, 19992016. MMWR Morb Mortal Wkly Rep, 67, 60-65. https://doi.org/10.15585/mmwr.mm6702a2
Perera, F. P. (2017). Multiple Threats to Child Health from Fossil Fuel Combustion: Impacts of Air Pollution and Climate Change. Environ Health Perspect, 125, 141-148. https://doi.org/10.1289/EHP299

Price, D., Bjermer, L., Bergin, D. A. and Martinez, R. (2017). Asthma referrals: a key component of asthma management that needs to be addressed. J Asthma Allergy, 10, 209-223. https://doi.org/10.2147/JAA.S134300

Pringle, A. (2013). Asthma and the diversity of fungal spores in air. PLoS Pathog, 9, e1003371. https://doi.org/10.1371/ journal.ppat.1003371

Quick, J. C. and Marland, E. (2019). Systematic error and uncertain carbon dioxide emissions from U.S. power plants. I Air Waste Manag Assoc, 69, 646-658. https://doi.org/10.1080/10962247.2019.1578702

Reinmuth-Selzle, K., Kampf, C. J., Lucas, K., Lang-Yona, N., Frohlich-Nowoisky, J., Shiraiwa, M., ... Poschl, U. (2017). Air Pollution and Climate Change Effects on Allergies in the Anthropocene: Abundance, Interaction, and Modification of Allergens and Adjuvants. Environ Sci Technol, 51, 4119-4141. https://doi.org/10.1021/ acs.est.6b04908

Reno, A. L., Brooks, E. G. and Ameredes, B. T. (2015). Mechanisms of Heightened Airway Sensitivity and Responses to Inhaled SO2 in Asthmatics. Environ Health Insights, 9, 13-25. https://doi.org/10.4137/EHI.S15671

Schultz, E. S., Litonjua, A. A. and Melen, E. (2017). Effects of Long-Term Exposure to Traffic-Related Air Pollution on Lung Function in Children. Curr Allergy Asthma Rep, 17, 41. https://doi.org/10.1007/s11882-017-0709-y

Strickland, M. J., Darrow, L. A., Klein, M., Flanders, W. D., Sarnat, J. A., Waller, L. A., ... Tolbert, P. E. (2010). Shortterm associations between ambient air pollutants and pediatric asthma emergency department visits. Am J Respir Crit Care Med, 182, 307-316. https://doi.org/10.1164/ rccm.200908-12010C

Takeda, M., Tanabe, M., Ito, W., Ueki, S., Konnno, Y., Chihara, M., ... Chihara, J. (2013). Gender difference in allergic airway remodelling and immunoglobulin production in mouse model of asthma. Respirology, 18, 797-806. https://doi.org/10.1111/resp.12078

Tran, P. and Tran, L. (2020). Comparisons between 2015 US asthma prevalence and two measures of asthma burden by racial/ethnic group. J Asthma, 57, 217-227. https://doi.org/10.1080/02770903.2018.1556686

Tzivian, L. (2011). Outdoor air pollution and asthma in children. J Asthma, 48, 470-81. https://doi.org/10.3109/ 02770903.2011.570407

Van Atten, C., Saha, A., Reynolds, L. and M.J. Bradley \& Associates (2012). Benchmarking Air Emissions of the 100 Largest Electric Power Producers in the United States. Available at: https://www.nrdc.org/sites/default/files/ benchmarking-2012.pdf

Walker, V. G. (2012). Factors related to emotional responses in school-aged children who have asthma. Issues Ment Health Nurs, 33, 406-429. https://doi.org/10.3109/ 01612840.2012 .682327 
Ware, J. H., Spengler, J. D., Neas, L. M., Samet, J. M., Wagner, G. R., Coultas, D., Ozkaynak, H. and Schwab, M. (1993). Respiratory and irritant health effects of ambient volatile organic compounds. The Kanawha County Health Study. Am J Epidemiol, 137, 1287-1301. https://doi.org/10.1093/ oxfordjournals.aje.a116639

Weaver, B. and Wuensch, K. L. (2013). SPSS and SAS programs for comparing Pearson correlations and OLS regression coefficients. Behav Res Methods, 45, 880-895. https://doi.org/10.3758/s13428-012-0289-7

Wolf, J., O’neill, N. R., Rogers, C. A., Muilenberg, M. L. and Ziska, L. H. (2010). Elevated atmospheric carbon dioxide concentrations amplify Alternaria alternata sporulation and total antigen production. Environ Health Perspect, 118, 1223-1228. https://doi.org/10.1289/ehp.0901867

Woodruff, T. J., Axelrad, D. A., Kyle, A. D., Nweke, O., Miller, G. G. and Hurley, B. J. (2004). Trends in environmentally related childhood illnesses. Pediatrics, 113, 1133-1140. Retrieved from https://pediatrics.aappublications.org/ content/pediatrics/113/Supplement_3/1133.full.pdf
Yaghoubi, M., Adibi, A., Safari, A., Fitzgerald, J. M. and Sadatsafavi, M. (2019). The Projected Economic and Health Burden of Uncontrolled Asthma in the United States. Am J Respir Crit Care Med, 200, 1102-1112. https://doi.org/10.1164/rccm.201901-0016OC

Yang, I. V., Lozupone, C. A. and Schwartz, D. A. (2017). The environment, epigenome, and asthma. J Allergy Clin Immunol, 140, 14-23. https://doi.org/10.1016/ j.jaci.2017.05.011

Zu, K., Liu, X., Shi, L., Tao, G., Loftus, C. T., Lange, S. and Goodman, J. E. (2017). Concentration-response of shortterm ozone exposure and hospital admissions for asthma in Texas. Environ Int, 104, 139-145. https://doi.org/10.1016 /j.envint.2017.04.006

Zu, K., Shi, L., Prueitt, R. L., Liu, X. and Goodman, J. E. (2018). Critical review of long-term ozone exposure and asthma development. Inhal Toxicol, 30, 99-113. https://doi.org/10.1080/08958378.2018.1455772

Zuo, B., Liu, C., Chen, R., Kan, H., Sun, J., Zhao, J., Wang, C., Sun, Q. and Bai, H. (2019). Associations between shortterm exposure to fine particulate matter and acute exacerbation of asthma in Yancheng, China. Chemosphere, 237, 124497. https://doi.org/10.1016/j.chemosphere.2019. 124497 